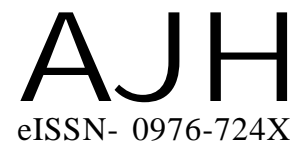

Received : 22.01.2016

Accepted : 26.05.2016
THEASIAN JOURNALOF HORTICULTURE

Volume 11 | Issue 1 | June, 2016 | 218-223

Visit us -www.researchjournal.co.in

A REVIEW
DOI : 10.15740/HAS/TAJH/11.1/218-223

\title{
A new vista of plant bio-regulators in fruit crops
}

\section{PRASHANT K. NIMBOLKAR, H.K. PORIKA ${ }^{1}$, SUNIL KUMAR ${ }^{2}$ AND B. SHIVA $^{1}$}

Members of the Research Forum

Associated Authors:

${ }^{1}$ Division of Fruit Crops, IIHR

BENGALURU (KARNATAKA) INDIA

${ }^{2}$ Division of Floriculture and Landscape Architecture, IIHR, BENGALURU (KARNATAKA) INDIA
Author for correspondence : PRASHANT K. NIMBOLKAR Division of Fruit Crops, IIHR, BENGALURU (KARNATAKA) INDIA Email : prashantnimbolkar11@ gmail.com

\begin{abstract}
A wide array of environment-friendly plant bio-regulators (PBRs) has received attention of researchers in horticulture. Bio-regulators, alternatively known as plant growth regulators (PGR) are natural or synthetic chemicals that affect the expression of biological responses in plant tissues. PBRs are used more extensively in tree fruit production than in any other horticultural or agricultural commodity, and they are essential for effective and profitable production. It plays an important role in growth and development of horticultural crops by sustaining their productivity and improving the quality of produce. The efficient utilization of plant bio-regulators can provide a dramatic change in fruit production despite all success in high density planting and improving quality yield and storage life of the fruits without any spoilage. Different plant bio-regulators like CPPU, salicylic acid, brassinosteroides, strigolactones, jasmonates, etc., have wide scope for exploration and application but are not widely accepted in commercial fruit production despite of their immense usefulness coupled with low hazard to human health.
\end{abstract}

KEY WORDS : PBR's, Propagation, Growth and development, Quality and yield.

HOW TO CITE THIS ARTICLE : Nimbolkar, Prashant K., Porika, H.K., Kumar, Sunil and Shiva, B. (2016). A new vista of plant bio-regulators in fruit crops. Asian J. Hort., 11(1) : 218-223, DOI : 10.15740/HAS/TAJH/11.1/218-223. 